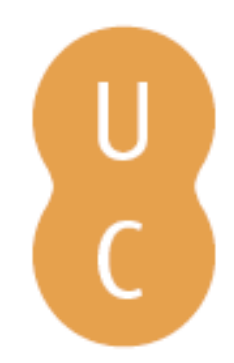

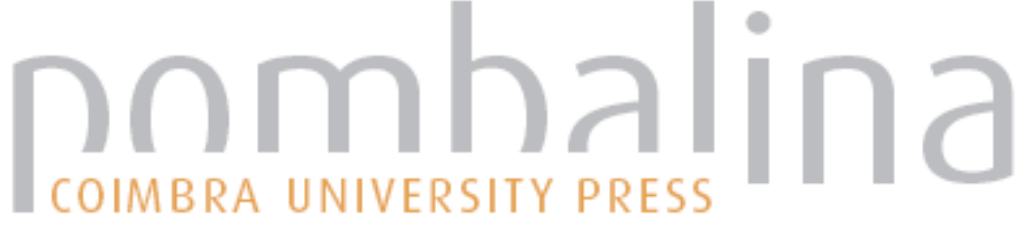

\section{Future time ambiguity types within younger and older adults}

Autor(es): $\quad$ Strizhitskaya, Olga Y.; Petrash, Marina D.

Publicado por: Imprensa da Universidade de Coimbra

URL

persistente:

URI:http://hdl.handle.net/10316.2/38610

DOI:

DOI:http://dx.doi.org/10.14195/978-989-26-0775-7_6

Accessed : $\quad$ 26-Apr-2023 12:39:26

A navegação consulta e descarregamento dos títulos inseridos nas Bibliotecas Digitais UC Digitalis, UC Pombalina e UC Impactum, pressupõem a aceitação plena e sem reservas dos Termos e Condições de Uso destas Bibliotecas Digitais, disponíveis em https://digitalis.uc.pt/pt-pt/termos.

Conforme exposto nos referidos Termos e Condições de Uso, o descarregamento de títulos de acesso restrito requer uma licença válida de autorização devendo o utilizador aceder ao(s) documento(s) a partir de um endereço de IP da instituição detentora da supramencionada licença.

Ao utilizador é apenas permitido o descarregamento para uso pessoal, pelo que o emprego do(s) título(s) descarregado(s) para outro fim, designadamente comercial, carece de autorização do respetivo autor ou editor da obra.

Na medida em que todas as obras da UC Digitalis se encontram protegidas pelo Código do Direito de Autor e Direitos Conexos e demais legislação aplicável, toda a cópia, parcial ou total, deste documento, nos casos em que é legalmente admitida, deverá conter ou fazer-se acompanhar por este aviso. 


\section{INTERNATIONAL \\ STUDIES IN TIME \\ PERSPECTIVE}

MARIA PAULA PAIXÃO

JOSÉ TOMÁS DA SILVA

(COORD.)

VICTOR ORTUÑO

PEDRO CORDEIRO

(EDITORS)

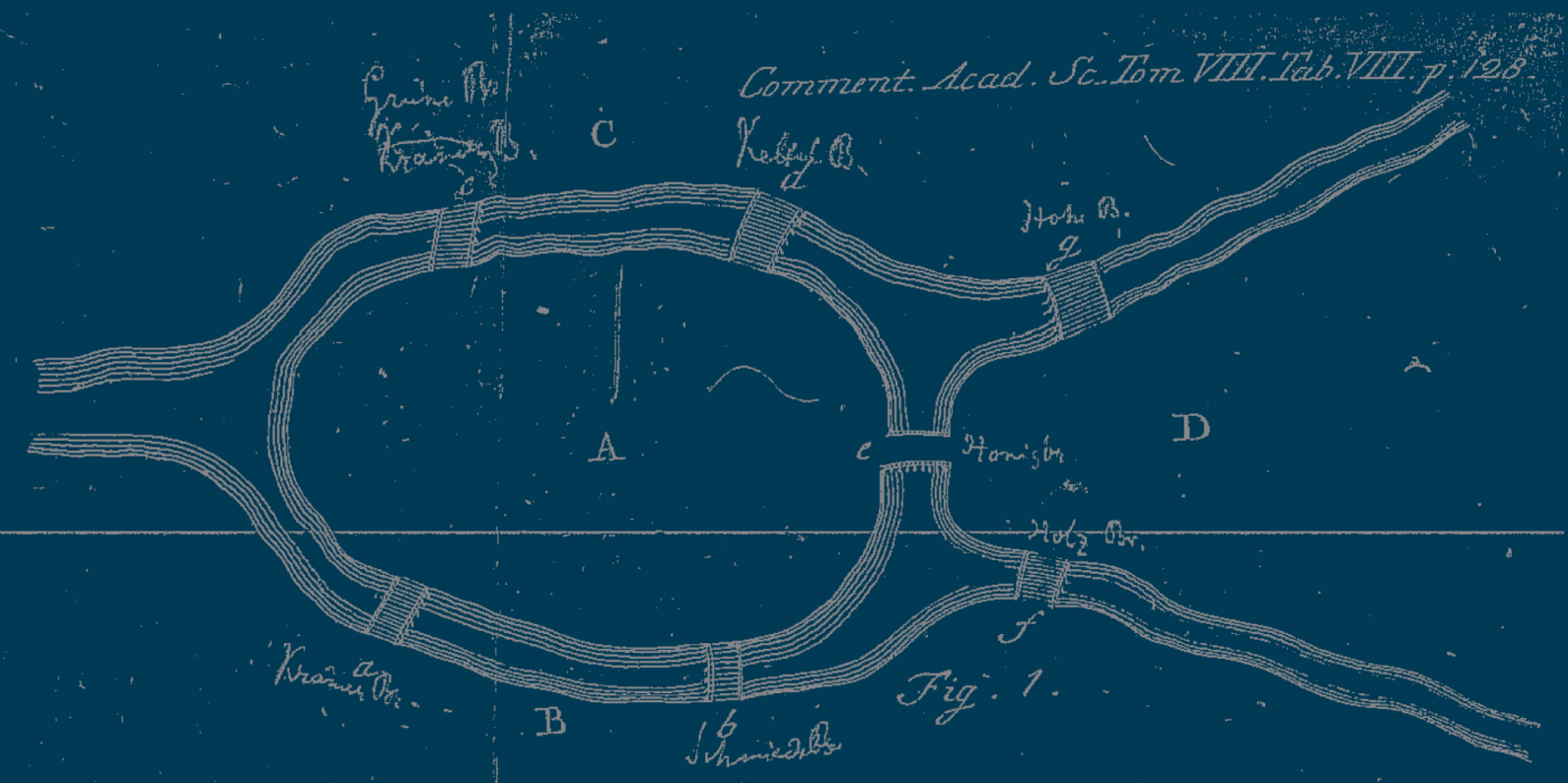

IMPRENSA DA

UNIVERSIDADE

DE COIMBRA

COIMBRA

UNIVERSITY

PRESS 


\title{
Chapter 6 \\ FUTURE TIME AMBIGUITY TYPES WITHIN YOUNGER AND OLDER ADULTS
}

\author{
Olga Y. Strizhitskaya \\ Marina D. Petrash \\ Faculty of Psychology, Saint Petersburg State University, Russian Federation \\ strizhitskaya@mail.ru
}

Aвstract: The current study presents research on future time ambiguity and its relation with personality characteristics. Ambiguity of future was traditionally considered to be a stressful factor. Our study revealed that with concern to ambiguity, respondents could be divided into 3 groups: (1) those having a clear idea of their future; (2) those having no idea of the future; (3) those whose attitude is perceiving the future as ambiguous. The sample was initially divided into two: young adults (aged 17-20, $n=60$ ), older adults (aged 45-60, $n=187$ ). Different content of the future in these 3 groups was revealed. An analysis of personal characteristics and coping strategies revealed that the first and third groups, though using different mechanisms, show quite constructive and adaptive strategies of behavior, while the less adaptive group appeared to be the second. Lifespan analysis showed that though in both age samples the first and third groups are most adaptive, they are still using different mechanisms. Results showed that ambiguity remains quite an underdeveloped construct, which considers positive and negative components, among which ambiguity as unclearness of future time plays more of a negative role, and the conceptual attitude to the future as unidentified and undetermined has a positive effect.

Keywords: types of time ambiguity, adult development.

\section{INTRODUCTION}

Future time has been attracting people since the beginning of times. One of the reasons we could imagine for this is that the concept of the future possesses a potential quality. Still closely associated with reality, the future remains an extremely urgent subject matter. In the present study we are looking at the future as a part of psychological lifespan time, in other words, one's psychological lifespan time is seen as integrity of psychological past, present and future. A subjective picture of lifespan reflects different objective life events and at the same time is a totally subjective mental projection, which has different functions. The psychological future is changeable, which is what makes it an attractive resource of development and self-actualization.

Among the diversity of existing psychological time theories and theories of future time as part of it (De Volder \& Lens, 1982; Miller \& Brickman, 2004; Ong \& Bergeman, 2004; Shmotkin \& Eyal, 2003; Simons, Vansteenkiste, Lens \& Lacante, 2004; Zimbardo \& Boyd, 2008; Golovakha \& Kronik, 1984; Nuttin, 2004; Regush, 2003), most authors 
agree that one's life and motives are constructed in a certain "field", the working space of which can be measured. In dangerous and stressful situations life perspective can decrease to the closest future goals and events, but during periods of calm reflection it can be broaden to remote moments in the past and future and even go out of life time limits (Zimbardo, 2008).

Another source for the concept of future can be seen in cognitive processes that provide formation of "temporal signs". Integrity of such signs provides time perspective for behavior functioning. Results from Nuttin's (2004) studies showed that objects of time perspective are determinants that regulate behavior, and length of perspective plays a significant role in making behavior plans and projects. Western studies of future construction are, for the most part, based on a concept of "future time perspective" (FTP - De Volder\&Lens, 1982). Future time perspective in this approach is considered as a cognitive and motivational concept, since it originates from setting motivational goals (Nuttin, 2004) and there can be found motivational effects determined by individual differences in future time perspective.

Ambiguity was traditionally considered as part of an extreme, stressful situation (Ross $\&$ Nisbett, 1999). And such a vision of ambiguity gave negative sense and functions to this notion. But when getting closer to this problem, we find that ambiguity is not such a oneway phenomenon. Comparing to distance, when the perspective is not clear, people are prone to overestimate distances. On the other hand, when contours are clear and obvious, people tend to underestimate the distance. Similarly, people are prone to overestimate the probability of simple events, and underestimate that of complicated ones. Another view of dual nature of ambiguity is hidden within the decision making process (Regush, 2003). While the situation is definite, non-ambiguous, we use ready concepts, notions and behavior patterns to solve a problem. Conversely, in ambiguous situations we need to upgrade our opinions, knowledge and patterns to stay efficient in our behavior; in other words, we need to develop. And here we get to the main dilemma: ambiguity causes anxiety - and that is bad; lack of knowledge, revealed by ambiguity, causes development - that is good.

In the present study we decided to take a little wider look at this problem. Our first idea was that people differ in terms of the extent to which they perceive their future as ambiguous. The second idea was that it's not just ambiguity that determines how we react, but also our personality: we supposed that different people will be experiencing ambiguity differently depending on their personal characteristics. And thus our aim was to study what the types of anxiety might be and also how people with different types would differ. Another study question was whether the same personality characteristics appear as crucial in different age periods. For comparison, we took samples from younger and older adulthood to see the most evident changes, if any.

\section{Method}

\section{Participants}

The sample consists of two subsamples: (1) $2^{\text {nd }}$ year students of Saint Petersburg Universities, aged 18-20 ( $M_{\text {age }}=18.5$ years, $\left.S D=0.43\right)$, both male and female ( $\left.\mathrm{f}=39 ; \mathrm{m}=21\right)$; (2) 135 women aged $45-60\left(M_{\text {age }}=51.84\right.$ years, $\left.S D=4.78\right)$. Due to the demographic 
situation, we didn't manage to get a relevant male sample for the older group. Each sample was divided into three groups based on their self-estimation of "future time ambiguity". Based on this scale we ascertained a "definite" group - those for whom the future is clear, planned and obvious; an "ambiguous" group - those on the edge, for whom nothing is defined in their life, nothing is $100 \%$ sure, and who believed that you can't know what your future would be like. "Definite" and "ambiguous" participants represented extreme meanings on the scale. The last group we called "unclear" - these were people who were "not sure" and "don't know really".

\section{Measures}

Cognitive image of the future. To measure cognitive image of future time we used a modified psychosemantic method, developed by E.I. Golovakha, A.A. Kronik (Golovakha $\&$ Kronik, 1984). This method consists of 21 pairs of adjectives, which respondents measure on a scale from 1 to 6 . One of the pairs - "definite - ambiguous" in concern to future time was taken to divide samples into groups.

Emotional image of the future. To measure emotional attitude to the future in the context of lifespan time we used "Emotional attitude to future" by V.R. Ginsburg, modified by V. Manukyan. Participants were asked to estimate the emotions (optimism, confidence, interest, indifference, anxiety and hopelessness) they feel for the past, present and future on a scale from 1 to 10. For study purposes new composites were computed: "positive" and "negative" attitude to time (past, present and future respectively). Indifference variable was interpreted as absence of emotional attitude.

Self-attitude. Adult self-attitude was assessed using "Method of self-attitude study" by S. Pantileev (Pantileev, 1993). Self-attitude was measured with 57 items with "Yes/ No" answers falling into 1 integral, 4 global and 7 differential scale of self-attitude. For the current study purposes we used an integral measure of self-attitude as a baseline for a ratio. The integral level of self-attitude in older adults $(M=.67 ; S D=.12)$ indicated a comparatively consistent positive attitude towards "self" in the present sample.

Locus of control was measured using Locus of Control Scale (LCS) developed by J. Rotter (Phares, 1976) and adapted in Russia by Bazhin et al. (Bazhin et al., 1984). Coping behavior was estimated using Lazarus coping-test adapted in Russia (Wasserman L.I., Ababkov V.A. \& Trifonova E.A., 2010).

\section{RESUlts}

Participants' characteristics analysis in groups revealed a interesting picture. Although we hoped to see that the "ambiguous" group would be the most adaptive and ready-tochange, the results showed another situation. For instance, "definite" and "ambiguous" were, in some sense, both "definite" groups. Only the first one believed they can plan everything, and these were people with quite a high level of locus of control. "Ambiguous" participants also had quite a clear idea of how things work in life and not making plans was more their conceptual attitude to life. Really unclear was the third group - their estimations in different spheres were contradictory and at some point that this unclearness started from their own inner lack of self-confidence. 
First group. Participants who replied as seeing their future as definite, had relevantly high levels of self-attitude (.68 for younger adults; .72 for older adults) and locus of control (.71 for younger adults; .74 for older adults). Correlation matrixes in both groups revealed greater connection with characteristics of past, both emotional and cognitive. As for coping strategies, both groups preferred such strategies as accepting responsibility and control over the situation. At the same time, we found some differences between these two samples. Though general patterns were very similar, younger adults still showed more integrated correlation matrix, both between characteristics of time perspective and personal characteristics, while older adults didn't show such an integration. Still, what we can definitely say about the first group is that for them the foundation of their future time confidence is in their past - as we could ascertain for younger adults: when their past is reliable, consistent and supporting, that helps them to expect something similar from their future. For older adults we couldn't establish such a correlation, maybe because life experience of an older adult is much more complicated and older adults are not so prone to make "black-and-white" judgments.

Second group. The "Unclear" group showed quite a different picture. Most correlations between time perspective and personality characteristics were focused around present time. Another specific feature of this group was ambivalent correlations - when the same characteristic or emotion could have both positive and negative effects. Comparing to the first group, they would have slightly lower levels of self-attitudes and locus of control, albeit not big enough to be significant. Comparison of younger and older adults also showed some differences. If younger adults didn't show any correlations to past or future characteristics of time perspective, the older sample revealed some. While younger adults showed contradictory connections between how they perceived their present (or past), the older group appeared to be more consistent, and their lifetime perspective seemed to be more integrated. So, at this point we could see that perception of ambiguity of future time and its connection with personality characteristics is not stable over lifespan.

Third group. The general pattern of the third group is orientation for future time. Their correlation matrix revealed, for both samples, less correlations in general, and those few focused on the future. Still, some differences were revealed for younger and older adults. First, it's curious to mention that in the older sample, the amount of participants who fall in the third group was almost twice as big as for other groups $\left(n_{1}=52 ; n_{2}=48 ; n_{3}=87\right)$, while in younger sample the amount is almost equal $\left(n_{1}=23 ; n_{2}=21 ; n_{3}=16\right)$. Second, in the younger adult sample, participants from the third group had quite a differentiated correlation structure, while older adults showed a more consistent and integrated picture, with a strong accent on the future. This picture seems similar to the changes we saw in the second group, and in some ways, we could say that these changes reveal personal maturation that occurs over lifespan.

\section{Conclusions \& Discussion}

The presented study was able to prove that future time ambiguity is not a homogenous phenomenon and can and should be considered with concern to its correlations with different personality traits. We found that future time ambiguity can be a kind of life attitude, or, in some sense, a motivational source that would affect the whole life management of a person. 
But this type of ambiguity can't be treated as a stressful factor, on the contrary; it describes personalities flexible in their life attitudes, open to new experiences, considering their life as a set of opportunities. Still we found a specific type of future time ambiguity, which is stressful and describes people who don't have any clear idea of their future and appear to be confused - but they are not those who would tell you that their future is ambiguous, uncertain or doubtful - they would rather stay unclear in their statements.

Also, the present study revealed that the three determined groups exist both in younger and older adult samples. Though having similar patterns, younger and older adults still showed some differences. We could show that perception of future time ambiguity and its connection to other personality traits is not stable over lifespan.

At the same time, the current study had some limitations. First of all, the study design didn't let us establish if type of future time ambiguity is stable over lifespan. Having a cross-sectional study we could only reveal that all three types exist in both samples, but only longitudinal study would let us see if it could be changed over years, though, assuming that perceiving of future time ambiguity is somehow connected to locus of control and self-attitude, we would rather propose that it would be consistent within one person. Still, that would be an assumption. Secondly, in our study we used only a limited set of methods to check if the original hypothesis has the right to exist. However, there could be a much wider range of personal and behavioral characteristics that could be connected, affecting or mastered by future time ambiguity. And that is what we see as future directions for the study.

\section{REFERENCES}

De Volder, M. L., \& Lens, W. (1982). Academic achievement and future time perspective as a cognitive-motivational concept. Journal of Personality and Social Psychology, 42 , 566-571.

Miller R. \& Brickman S. (2004). A Model of Future-Oriented Motivation and Self-Regulation. Educational Psychology Review, 16 (1), 9-33.

Ong A. \& Bergeman C. (2004). Resilience and Adaptation to Stress in Later Life: Empirical Perspectives and Conceptual Implications. Ageing International, 29 (3), 219-246.

Shmotkin, D. \& Eyal, N. (2003) Psychological Time in Later Life: Implications for Counseling. Journal of Counseling \& Development. 81(3), 259-268.

Simons J., Vansteenkiste M., Lens W. \& Lacante M. (2004). Placing Motivation and Future Time Perspective Theory in a Temporal Perspective. Educational Psychology Review, 16 (2), 121-139.

Zimbardo, P. G. \& Boyd, J. (2008). The Time Paradox: The New Psychology of Time That Will Change Your Life. New York: Simon \& Schuster.

Бажин Е.Ф., Голынкина Е.А., Эткинд А.М. [Bazhin E.F., Golynkina E.A., Etkind A.M.] (1984) Метод исследования уровня субъективного контроля [Method of subjective control study]// Психологический журнал [Psychological Journal]. - Том 5. -1984. - n. o 3. - С.152162.

Вассерман Л.И., Абабков В.А., Трифонова Е.А. [Wasserman L.I. Ababkov V.A., Trifonova E.A.] (2010) Совладание со стрессом: теория и психодиагностика [Coping with stress: theory and psychodiagnostics]. Saint-Petersburg, Russia: Rech Publishing.

Головаха Е.И. \& Кроник Л.Л. [Golovakha E.I., Kronik A.A.] (1984) Психологическое время личности [Psychological time of personality]. Kiev, Ukraine: Naukova Dumka. 
Нюттен Дж. [Nuttin J.] (2004) Мотивация, действие и перспектива будущего [Motivation, action and future time perspective]. Moscow, Russia: Smysl Publishing.

Пантилеев C. P. [Pantileev S.R.] (1993) Методика исследования самоотношения [Method of self-attitude study]. Moscow, Russia: Smysl Publishing.

Регуш Л.A.[Regush L.A.] (2003) Психология прогнозирования: успехи в познании будущего [Psychology of forecasting: ]. Saint-Petersburg, Russia: Rech Publishing.

Pocc Л., Нисбетт P. [Ross L., Nisbett R.] (1999) Человек и ситуация [Person and situation]. Moscow, Russia: Aspect Press. 